\title{
Karakteristik Penyedap Rasa Alami dari Biji Bunga Matahari dan Kupang Putih dengan Hidrolisis Enzimatis
}

\section{Characteristics of Natural Flavors of Sunflower Seeds and White Kupang with Enzymatic Hydrolysis}

\section{Luqman A. Wicaksono, Sri Winarti*}

Program Studi Teknologi Pangan, Fakultas Teknik, Universitas Pembangunan Nasional "Veteran" Jawa Timur, Jl. Raya Rungkut Madya, Gunung Anyar, Surabaya, 60294

*Penulis korespondensi: Sri Winarti, e-mail: sriwinarti.tp@upnjatim.ac.id

Tanggal submisi: 19 Februari 2021; Tanggal penerimaan: 19 April 2021

\begin{abstract}
Research has been carried out on the production of natural flavorings from sunflower seeds and white shells by an enzymatic process using endo- and exo-protease enzymes from papaya sap (papain) and biduri plant sap (calotropin). The study aimed to determine the effect of the concentration of the mixture of endoand exo-protease enzymes and the incubation time on the characteristics and profiles of amino acids of natural flavoring from sunflower and white shells. A completely randomized design (CRD) which consisted of 2 factors, the enzyme concentration ( $0 ; 1.5 ; 3.0$ and $4.5 \%)$ and the hydrolysis time $(1,2$ and 3 hours)was applied in this research. The obtained data were subjected to analysis of variance. The Duncan multiple range test was used to see whether there were any significant differences between treatments. The results showed that the concentration of the mixture of endo- and exo-protease enzymes and incubation time significantly affected the degree of hydrolysis, dissolved protein, water content, Maillard product, water solubility index, oil absorption and yield. The best treatment in this study was the enzyme concentration of calotropin:papain 3\% and 2 hours of incubation, resulting in flavoring with the characteristics: degree of hydrolysis of 96.81\%; dissolved protein of $52.86 \%$; Maillard products of $0.162 \%$; water solubility index of 0.036 ; oil absorption of $1.88 \%$; and the glutamic acid content of $78.678 \mathrm{mg} / \mathrm{g}$.
\end{abstract}

Keywords: Calotropin; flavorings; papain; sunflower seed; white shells

(c) Penulis. Penerbit Universitas Pattimura. Akses terbuka dengan lisensi CC-BY-SA.

\begin{abstract}
ABSTRAK
Telah dilakukan penelitian pembuatan penyedap rasa alami dari bahan baku biji bunga matahari dan kupang putih secara enzimatis menggunakan endo- dan ekso-enzim protease dari getah papaya (papain) dan getah tanaman biduri (calotropin). Tujuan penelitian adalah mengetahui pengaruh konsentrasi campuran endodan ekso-enzim protease, serta lama inkubasi terhadap karakteristik dan profil asam amino penyedap alami dari bunga matahari dan kupang putih. Rancangan penelitian adalah rancangan acak lengkap yang tersusun atas dua faktor, yaitu konsentrasi enzim $(0 ; 1,5 ; 3,0$ dan 4,5\%) dan waktu hidrolisis ( 1,2 dan 3 jam). Data yang diperoleh dianalisis menggunakan analisis keragaman, dan uji beda rataan menggunakan uji jarak berganda Duncan. Hasil penelitian menunjukkan bahwa konsentrasi campuran endo- dan ekso-enzim protease serta lama inkubasi berpengaruh nyata terhadap derajat hidrolisis, kadar protein terlarut, kadar air, produk maillard, indeks kelarutan air, daya serap minyak, dan rendemen penyedap rasa yang dihasilkan. Perlakuan terbaik pada penelitian ini adalah konsentrasi enzim calotropin:papain 3\% dan lama inkubasi 2 jam, menghasilkan penyedap rasa dengan karakteristik: derajat hidrolisis $96,81 \%$; kadar protein terlarut $52,86 \%$; produk maillard $0,162 \%$; indeks kelarutan air 0,036; daya serap minyak 1,88\% dan kadar asam glutamat mencapai 78,678 mg/g.
\end{abstract}

Kata kunci: Biji bunga matahari; calotropin; kupang putih; papain; penyedap rasa

(c) The Authors. Publisher Universitas Pattimura. Open access under CC-BY-SA license. 


\section{PENDAHULUAN}

Penyedap rasa merupakan salah satu bahan tambahan (zat aditif) yang diberikan pada masakan dengan tujuan untuk memperkuat rasa pada masakan dan digunakan secara instan supaya masakan menjadi lebih lezat dengan takaran bumbu yang sedikit. Salah satu penyedap rasa yang sering digunakan pada pengolahan makanan adalah monosodium glutamat (MSG). Menurut Nuryani dan Jinap (2010), MSG adalah garam natrium yang berikatan dengan asam amino berupa asam glutamat. MSG berbentuk kristal putih yang stabil, tetapi dapat mengalami degradasi oleh oksidator kuat. Meskipun diijinkan sebagai penyedap masakan, penggunaan MSG berlebihan bisa mengakibatkan rasa pusing dan mual.

MSG dalam makanan berfungsi menambah citarasa, meningkatkan rasa enak atau menekan rasa yang tidak diinginkan. Asam glutamat mengelabuhi otak seakan telah merasakan sesuatu yang lezat. Dampak inilah yang disebut dengan eksitosin. Eksitosin merupakan salah satu faktor yang memperparah terjadinya alzhemair, multiple sclerosis, stroke dan parkinson (Mulyono, 2006). Menurut laporan masyarakat ke Food Drug Administration (FDA), 2\% dari seluruh pengguna MSG mengalami masalah kesehatan, sehingga WHO menetapkan acceptable daily intake untuk manusia sebesar 120 $\mathrm{mg} / \mathrm{kg}$ (Setiyawati, 2008). Hasil penelitian Bhattacharya (2011) yaitu mencit yang diberi MSG dosis $2 \mathrm{mg} / \mathrm{bb} / \mathrm{hr}$ selama 75 hari menemukan adanya perubahan histologi pada hepar, yang meliputi kerusakan inti hepatosit, inflamasi, dan peningkatan diameter hepatosit.

Berdasarkan hal tersebut, maka pengembangan sumber cita rasa alternatif perlu dilakukan. Diharapkan cita rasa alternatif tersebut tidak hanya berfungsi dalam menciptakan rasa gurih pada makanan, tetapi juga memberikan peran nutrisi dan aman bagi kesehatan. Untuk mengurangi jumlah penggunaan MSG, masyarakat dapat memanfaatkan bahan-bahan alami yang mengandung protein tinggi sebagai alternatif pengganti bahan tambahan buatan, antara lain biji bunga matahari (sumber protein nabati) dan kupang putih (sumber protein hewani).

Biji bunga matahari merupakan sumber protein nabati (Venktesh dan Prakash, 1993). Setiap $100 \mathrm{~g}$ biji mengandung protein $20,78 \mathrm{~g}$, total lipid (lemak) 51,46 g, abu 3,02 g, karbohidrat 20,0 g dan serat $8,6 \mathrm{~g}$ dengan total energi $2445 \mathrm{kj}$. Biji bunga matahari juga merupakan sumber kolin $(55,1 \mathrm{mg})$ dan sisteine (35,4 mg) (USDA, 2008). Seluruh biji bunga matahari mengandung air $5,50 \%$, protein $18,72 \%$, lemak kasar 37,47\%, serat kasar 28,30\%, abu 3,49\% dan karbohidrat 6,11\%. Bunga matahari adalah tanaman biji minyak yang dibudidayakan di seluruh dunia untuk sumber minyak dan protein (Ravindran dan Blair, 1992). Komponen gizi yang terkandung dalam daging kupang putih (Corbula faba Hinds) meliputi kadar air 72,96\%, kadar abu $3,80 \%$, kadar protein $9,05 \%$, kadar lemak $1,50 \%$, dan kadar karbohidrat 1,02\% (Baswardono, 1983). Kupang memiliki sumber asam amino esensial yang baik. Kupang putih memiliki 17 asam amino, sedangkan dari 17 asam amino tersebut terkandung 10 macam asam amino esensial yang diperlukan untuk tubuh. Analisis kuantitatif kadar asam amino kupang putih antara lain mengandung aspartat $1,061 \%$, glutamat $1,443 \%$ dan alanine $0,869 \%$ (Purwanto dan Sarjimah, 2000). Kupang merupakan hasil laut yang pemanfaatannya belum optimal.

Rasa gurih dapat dihasilkan dari bahan-bahan alami yang mengandung tinggi protein, maka perlu dilakukan hidrolisis terhadap protein tersebut. Hasil penelitian Subagio (2002), menjelaskan bahwa hasil hidrolisis protein tempe oleh enzim protease menghasilkan peptida-peptida pendek yang mempunyai rasa gurih. Penelitian tersebut membawa pada pemikiran bahwa hasil hidrolisat protein oleh enzim protease berpotensi sebagai bahan penyedap rasa pengganti MSG.

Sun (2011) mengemukakan bahwa terdapat dua metode untuk menghidrolisis protein, yaitu hidrolisis asam dan hidrolisis enzimatis. Hidrolisis asam mulai dihindari oleh kebanyakan industri makanan, karena produk yang dihasilkan kurang aman untuk kesehatan. Hidrolisis enzimatis merupakan pilihan metode yang aman, enzim yang sering digunakan adalah bromelin dan papain. Menurut Kunts (2000), produk hidrolisis protein mempunyai ruang aplikasi yang luas terkait dengan sifat fungsional atau sifat nutrisinya. Mengingat enzim protease untuk industri pangan selama ini kebanyakan masih impor dan harganya relatif mahal, maka perlu dikembangkan pemanfaatan enzim protease dari bahan lokal Indonesia, salah satunya adalah enzim papain dari getah pepaya dan enzim protease dari getah tanaman biduri (calotropin).

Pepaya (Carica papaya L.) adalah tumbuhan penghasil enzim papain yang merupakan golongan enzim protease sulfihidril (Dongoran, 2004) jenis endo-peptidase yang dapat memecah rangkaian asam amino dari bagian dalam atau tengah. Suhu optimal enzim papain antara $50-60^{\circ} \mathrm{C}$ (Winarno, 2002). Calotropin dari tanaman biduri (Calotropis 
gigantean) adalah salah satu jenisnya enzim proteolitik asli dari Indonesia. Berdasarkan pola pemecahan substratnya, protease biduri terindikasi dalam golongan ekso-peptidase yang sangat poten-sial untuk proses pembuatan hidrolisat protein maupun untuk memperbaiki flavor produk pangan tertentu. Karakteristik enzim ini adalah optimum pada $\mathrm{pH}$ sekitar 7 dan suhu sekitar $55^{\circ} \mathrm{C}$, yang termasuk dalam protease termostabil. Inaktivasi protease biduri dapat dilakukan dengan pemanasan suhu $90^{\circ} \mathrm{C}$ selama 10 menit atau suhu $80^{\circ} \mathrm{C}$ selama10-30 menit, sedangkan pemanasan suhu $60^{\circ} \mathrm{C}$ akan inaktif selama 30 menit (Witono, 2013).

Hidrolisis menggunakan enzim dapat dilakukan dengan menggunakan satu jenis enzim atau beberapa jenis enzim yang berbeda. Penggunaan campuran proteolitik lebih efektif dibandingkan penggunaan enzim tunggal, dengan jumlah enzim yang sama dapat digunakan untuk menghidrolisis substrat yang lebih banyak (Witono, 2014). Oleh karena itu dalam peneltian ini dilakukan pembuatan penyedap rasa dari biji bunga matahari dan kupang putih menggunakan enzim campuran yaitu papain dan calotropin. Tujuan penelitian adalah mengetahui pengaruh konsentrasi campuran endo- dan eksoenzim protease $(0 ; 1,5 ; 3,0$ dan $4,5 \%)$, serta lama inkubasi (1, 2 dan 3 jam) terhadap karakteristik dan profil asam amino penyedap alami dari bunga matahari dan kupang putih.

\section{METODE PENELITIAN}

\section{Bahan}

Bahan baku yang digunakan dalam penelitian ini adalah kupang putih yang diperoleh dari nelayan pantai Kenjeran, Surabaya dan biji bunga matahari yang diperoleh kopesasi Makmur Pasuruan. Bahan tambahan yang digunakan meliputi getah tanaman biduri dan getah pepaya muda yang diperoleh dari pinggir danau UPN "Veteran" Jawa Timur.

\section{Prosedur Penelitian}

\section{Ekstraksi Enzim dari Tanaman Biduri (Witono, 2011)}

Tanaman biduri disadap getahnya dengan melukai/memotong tanaman biduri pada bagian atas (pucuknya). Penampungan getah dalam akuades dingin $\left(12^{\circ} \mathrm{C}\right)$ yang mengandung $0,7 \quad \% \quad \mathrm{Na}-$ metabisulfit $\mathrm{pH}$ 3,5 (Sigma, USA) dengan perbandingan 1:4 (Witono, 2011). Selanjutnya, dilakukan uji aktivitas protease metode Lowry (Walker, 1994).

\section{Ekstraksi Enzim dari Buah Pepaya (Suyanti et al., 2012 dan Winarti, 2007)}

Buah pepaya muda disadap getahnya dengan menorehkan pisau pada kulit buah mulai dari pangkal menuju ujung buah. Pencampuran getah pepaya dengan Na-metabisulfit $0,7 \%$ dengan perbandingan 1:4 (Suyanti et al., 2012 dan Winarti, 2007). Selanjutnya, dilakukan uji aktivitas protease metode Lowry (Walker, 1994).

\section{Pembuatan Penyedap Rasa dari Hidrolisat Kupang Putih dan Biji Bunga Matahari}

Sebelum direbus, kupang putih dicuci sampai bersih. Perebusan dilakukan menggunakan api kecil pada suhu $50^{\circ} \mathrm{C}$ selama 2 jam. Perebusan ini bertujuan untuk membuka cangkang kupang dan untuk melunakan jaringan. Daging kupang dicuci kembali dan dipisahkan kulitnya, selanjutnya dihaluskan menggunakan crusher dengan perbandingan kupang dan air (1:1) (b/v). Biji bunga matahari yang telah dikupas kulitnya dicuci bersih kemudian direbus selama 10 menit pada suhu $100^{\circ} \mathrm{C}$. Selanjutnya dihaluskan menggunakan crusher dengan perbandingan biji bunga matahari:air (1:1) (b/v). Setelah diperoleh slurry, sebanyak $50 \mathrm{~mL}$ slurry kupang putih dan $50 \mathrm{~mL}$ slurry biji bunga matahari dicampur dan diatur $\mathrm{pH}$-nya menjadi 7 , kemudian ditambahkan 0,6\% L-sistein (Sigma, USA) dan enzim biduri dan papain konsentrasi 0,2 $\%$ dengan proporsi sesuai perlakuan. Selanjutnya dihidrolisis pada suhu $55^{\circ} \mathrm{C}$ selama waktu sesuai perlakuan. Dipanaskan pada suhu $100^{\circ} \mathrm{C}$ selama 15 menit untuk inaktivasi enzim. Hidrolisat ditambahkan ingredien lain seperti 13,3\% glukosa lokal (b/v), 13,3\% garam teknis (b/v), dan 13,3\% gula karamel teknis (b/v) dan maltodekstrin $0,4 \%$ teknis dari berat bahan awal. Selanjutnya dikeringkan $60^{\circ} \mathrm{C}$ menggunakan cabinet dryer selama 18 jam, kemudian digiling dan diayak menggunakan ayakan 80 mesh sehingga didapatkan serbuk penyedap rasa.

\section{Uji Aktivitas Protease (Metode Lowry-Walker, 1994)}

Pengujian aktifitas enzim protease menggunakan substrat soluble casein pada $\mathrm{pH} \mathrm{7,} \mathrm{dengan}$ tahapan sebagai berikut: menimbang 0,01 g soluble casein dalam tabung sentrifuse lalu dicampur dengan $3 \mathrm{~mL}$ buffer fosfat $\mathrm{pH}$ 7. Kemudian dilakukan pra inkubasi pada suhu $37^{\circ} \mathrm{C}$ selama 4 menit. Selanjutnya kedalam sampel ditambahkan 0,250 mL untuk filtrat getah atau $0,005 \mathrm{~g}$ untuk crude protease kering ke dalam campuran, kemudian dilakukan inkubasi pada suhu $55^{\circ} \mathrm{C}$ selama 20 menit. Pada 
akhir inkubasi reaksi hidrolisis dihentikan dengan menambahkan $1 \mathrm{~mL}$ larutan TCA 15\%. Sebagai kontrol tanpa inkubasi dan reaksi hidrolisis dilakukan pada waktu 0 menit, dimana penambahan larutan TCA $15 \%$ dilakukan sebelum penambahan protease. Selanjutnya disentrifus menggunakan sentrifugasi pada kecepatan $1000 \mathrm{rpm}$ selama 10 menit. Supernatan yang diperoleh diambil $1 \mathrm{~mL}$ lalu di tambahkan 2,5 mL mix-Lowry dan dibiarkan 10 menit. Selanjutnya ditambahkan $0,250 \mathrm{~mL}$ reagen follin dan dibiarkan selama 30 menit. Ditambahkan akuades sampai volume $5 \mathrm{~mL}$ dan dibaca absorbannya menggunakan spectrometer UV-Vis D21 (Shimadzu, Jepang) pada panjang gelombang 750 nm. Data absorbansi diplotkan pada kurva standar tirosin (Sigma, USA) untuk dihitung aktivitas hidrolisisnya.

Perhitungan aktifitas spesifik enzim dapat menggunakan rumus sebagai berikut:

$$
1 \text { unit aktivitas }=\frac{[C]}{t} \times \frac{1000}{181,19}
$$

Keterangan: $[\mathrm{C}]=$ konsentrasi protein terlarut $(\mu \mathrm{mol}$ tirosin/ml), T = waktu hidrolisis (menit), 181,19 = berat molekul tirosin, 1 unit $=1 \mu$ mol tirosin yang di bebaskan dari substrat oleh setiap g enzim per menit pada kondisi optimum

\section{Derajat Hidrolisis metode soluble protein content in TCA (Silvestre, et al., 2013).}

Derajat hidrolisis diuji menurut Silvestri et al. (2013), sebagai berikut: sebanyak $1 \mathrm{~mL}$ sampel ditambah dengan $1 \mathrm{~mL}$ TCA 10\% (Sigma, USA), kemudian diinkubasi 30 menit setelah itu disentrifugasi $3000 \mathrm{rpm}$ selama 15 menit. Supernatan yang diperoleh selanjutnya dianalisis kadar protein terlarutnya menggunakan metode Lowry.

Persentase derajat hidrolisis $(\mathrm{DH})$ ditentukan dengan persamaan sebagai berikut:

$$
D H(\%)=\frac{\text { Protein terlarut dalam } 10 \% \text { TCA }(\mathrm{mg})}{\text { Total Protein }(\mathrm{mg})} \times 100 \%
$$

\section{Kadar Protein Terlarut Metode Lowry (Sudarmadji et al., 1997)}

Kadar protein terlarut diuji dengan metode Lowry, sebagai berikut: sebanyak 0,05 g sampel dilarutkan hingga $50 \mathrm{~mL}$. Larutan diambil sebanyak $1 \mathrm{~mL}$ kemudian ditambahkan hingga $4 \mathrm{~mL}$. Dilakukan penambahan $5,5 \mathrm{~mL}$ pereaksi Lowry A ke dalam masing-masing tabung reaksi, dicampur merata menggunakan vortex type Genius 3 (IKA) dan diinkubasi selama 15 menit. Dilakukan penambahan $0,5 \mathrm{~mL}$ pereaksi Lowry B ke dalam masing- masing tabung reaksi, dicampur merata menggunakan vortex dan diinkubasi selama 30 menit. Pengukuran absorbansi pada panjang gelombang $650 \mathrm{~nm}$ dengan menggunakan spektrofotometer UV-Vis D21. Blanko dibuat dengan cara yang sama tetapi tanpa sampel selanjutnya protein terlarut dapat dihitung dengan rumus yang diperoleh dari kurva standart dengan rumus $y=a x+b$ yang diperoleh dari kurva standart.

\section{Indeks Kelarutan Air metode sentrifugasi (Witono, 2013).}

Indeks kelarutan air penyedap alami yang diperoleh dianalisis sebagai berikut: sampel sebanyak $1 \mathrm{~g}$ dimasukkan ke dalam tabung sentrifus, kemudian ditambahkan akuades sebanyak $10 \mathrm{~mL}$ ke dalam tabung dan dikocok menggunakan vortex. Tabung selanjutnya disentrifugasi dengan kecepatan $2000 \mathrm{rpm}$ pada suhu ruang selama 15 menit. Supernatan yang diperoleh diambil sebanyak $2 \mathrm{~mL}$ dan dimasukan ke dalam botol timbang yang telah diketahui beratnya. Botol kemudian dimasukan ke dalam oven (Memmert, Jerman) dan dikeringkan pada suhu $110^{\circ} \mathrm{C}$ sampai semua air menguap. Botol kemudian didinginkan dan ditimbang untuk mengetahui berat bahan kering yang terdapat dalam supernatan.

Adapaun indeks kelarutan dalam air ditentukan dengan persamaan sebagai berikut:

$$
\text { IKA }\left(\frac{g}{m L}\right)=\frac{\text { Berat cawan setelah dioven-berat cawan }}{2 \mathrm{~mL}}
$$

Dimana: IKA = Indeks kelarutan air.

\section{Daya Serap Minyak (Beuchat, 1977)}

Pengujian daya serap minyak dilakukan sebagai berikut: sampel sebanyak $1 \mathrm{~g}$ dimasukkan kedalam tabung sentrifus lalu ditambahkan dengan $10 \mathrm{~mL}$ minyak nabati lokal, kemudian diaduk dengan spatula dan didiamkan pada suhu kamar selama 30 menit. Setelah itu disentrifugasi pada $3000 \mathrm{rpm}$ selama 30 menit. Volume minyak yang bebas atau tidak terserap oleh sampel, diukur dengan gelas ukur.

Perhitungannya sebagai berikut:

Daya serap minyak $(\mathrm{mL} / \mathrm{g})=\frac{(\text { volume awal }- \text { volume akhir })}{\text { berat } \text { sampel }}$

\section{Analisa Profil Asam Amino (Asam Glutamat) (AOAC, 1995).}

Profil asam amino penyedap rasa dilakukan terhadap produk dari perlakuan tarbaik. Sampel 
sebanyak $0,5 \mathrm{~g}$ dimasukkan ke dalam gelas piala 25 mL kemudian ditambahkan $\mathrm{HCl} 6 \mathrm{~N}$ (Sigma, USA) sebanyak $10 \mathrm{~mL}$. Gelas piala dipanaskan selama 24 jam pada suhu $100^{\circ} \mathrm{C}$. Sampel disaring dan diambil filtratnya. Filtrat ditambahkan $5 \mathrm{~mL}$ larutan pengering (metanol, picolotiocianat, tri-etilamin) (Sigma, USA), kemudian dikeringkan. Larutan derivatisasi (metanol, Na-asetat, dan trietilamin) ditambahkan dan sampel didiamkan selama 20 menit. Larutan asetat $1 \mathrm{M}$ (Sigma, USA) sebanyak $200 \mathrm{~mL}$ ditambahkan dan sampel siap diinjeksikan ke Ultra Performance Liquid Chromatography (UPLC, Waters, Prague, Czech Republic). Kondisi alat UPLC sebagai berikut: suhu pada suhu ruang, kolom yang digunakan adalah pico tag 3,9 × 150 $\mathrm{nm}$, kecepatan aliran $1,5 \mathrm{~mL} /$ menit, batas tekanan $3000 \mathrm{psi}$, program gradien, fase gerak asetonitril $60 \%$ (Sigma, USA) dan buffer natrium asetat $1 \mathrm{M}$ (Sigma, USA), dan detektor sinar UV dengan panjang gelombang $254 \mathrm{~nm}$.

Perhitungannya sebagai berikut:

Rasio $=$ Area Analit/Area AABA

$\mathrm{FP}=$ Volume $1 /$ Volume Pemipetan

C. Injeksi $(\mathrm{pmol} / \mu \mathrm{L})=($ Rasio Sampel $/$ Rasio Standar $) \times$ C. Standar Injeksi

Kadar Asam Amino $(\mathrm{mg} / \mathrm{Kg})=(($ Rasio Sampel $/$ Rasio Standar) $\times$ (C. Standar Injeksi/1000000000) $\times \mathrm{BM} \times \mathrm{FP} \times$ Volume Akhir $\times 1000$ ) $/$ Bobot Sampel (g)

Kadar Asam Amino (\%) = Kadar Asam Amino $(\mathrm{mg} / \mathrm{kg} ; \mathrm{mg} / \mathrm{L}) / 10000$

\section{Analisa Data}

Data yang diperoleh dianalisis menggunakan analisis keragaman, apabila perlakuan berpengaruh nyata atau sangat nyata, maka beda antar rataan perlakuan diuji lanjut dengan metode Duncan't Multiple Range Test (DMRT) $(\alpha=0,05)$.

\section{HASIL DAN PEMBAHASAN}

\section{Aktivitas Enzim Protease}

Crude protease yang diperoleh dari getah pepaya muda (enzim papain) dan crude protease dari getah tanaman biduri (enzim calotropin) diuji aktivitasnya menggunakan substrat kasein. Berdasarkan pola pemecahan substratnya, enzim papain yang merupakan golongan enzim protease sulfihidril, jenis endo-peptidase yang dapat memecah rangkaian asam amino dari bagian dalam atau tengah, sedangkan enzim protease biduri termasuk dalam golongan ekso-peptidase yang sangat potensial untuk proses pembuatan hidrolisat protein maupun untuk memperbaiki flavor produk pangan tertentu. Nilai aktivitas enzim protease papain kasar dan getah biduri kasar dapat dilihat pada Tabel 1.

Tabel 1. Aktivitas enzim protease papain dan calotropin kasar

\begin{tabular}{lcc}
\hline \multirow{2}{*}{ Enzim } & \multicolumn{2}{c}{ Aktivitas Enzim (Unit) } \\
\cline { 2 - 3 } & Hasil & Literatur \\
\hline Papain kasar & $1,045 \pm$ & $0,919^{*}$ \\
& 0,031 & \\
Calotropin kasar & $1,186 \pm$ & $0,074^{* *}$ \\
& 0,046 & \\
\hline
\end{tabular}

Sumber: *Ratnayani et al. (2015); **Witono (2011).

Pada Tabel 1, diketahui bahwa nilai aktivitas enzim papain kasar hasil pengujian adalah 1,045 unit sedangkan menurut Ratnayani et al. (2015) adalah 0,919 unit. Nilai aktivitas enzim papain kasar pada penelitian ini lebih besar dibandingkan dengan hasil penelitian Ratnayani et al. (2015). Perbedaan nilai aktivitas ini disebabkan karena pada penelitian ini menggunakan media ekstraksi natrium metabisulfit $0,7 \%$ untuk mencegah oksidasi. Hal ini sesuai dengan Witono (2011) bahwa kegunaan natrium metabisulfit yaitu untuk melindungi protein enzim, sehingga konformasinya tidak berubah atau tidak mudah rusak selama inkubasi selain itu juga sebagai antioksidan yang dapat mencegah kerusakan papain akibat oksidasi. Nilai aktivitas enzim calotropin kasar hasil pengujian adalah 1,186 Unit sedangkan menurut Witono (2011) adalah 0,074 Unit. Nilai aktivitas enzim getah biduri kasar pada penelitian ini lebih besar dibandingkan dengan hasil penelitian Witono (2011). Perbedaan nilai aktivitas ini disebabkan karena perbedaan $\mathrm{pH}$ dan suhu media ekstraksi media ekstraksi, pada penelitian Witono (2011) media ekstraksi yang digunakan adalah larutan Na-matabisulfit $0,7 \%$ tanpa pengaturan $\mathrm{pH}$ dan suhu sedangkan pada penelitian ini menggunakan larutan Na-matabisulfit 0,7\% pH 3,5 suhu $12^{\circ} \mathrm{C}$ perbandingan enzim dengan larutan 1:4. Menurut Witono (2011) pH ekstraksi berpengaruh terhadap rendemen dan unit aktivitas, kadar protein maupun aktivitas spesifik protease dari tanaman biduri. Presipitasi pada $\mathrm{pH}$ 3,5 dihasilkan protease biduri dengan rendemen, unit aktivitas maupun aktivitas spesifik paling tinggi. Perlakuan pada $\mathrm{pH}$ 3,5 merupakan $\mathrm{pH}$ isoelektrik bagi protein enzim biduri (Witono, 2011). Hal ini karena pada titik isoelektrik, protein mempunyai nilai kelarutan terendah, mengingat protein berada dalam bentuk 
zwitter ion (tidak memiliki muatan bersih) dan cenderung membentuk ion dipolar $\left(\mathrm{NH}^{3+}\right.$-CHR$\left.\mathrm{COO}^{-}\right)$.

\section{Karakteristik Penyedap Rasa Alami}

Karakteristik penyedap rasa alami dari biji bunga matahari dan kupang putih yang dianalisa meliputi: derajad hidrolisis, protein terlarut, produk maillard, indeks kelarutan air dan daya serap minyak. Hasil pengamatan disajikan pada Tabel 2.

\section{Derajad Hidrolisis}

Rata-rata derajat hidrolisis dari hidrolisat biji bunga matahari+kupang putih berkisar antara 60,886-96,81\%. Perlakuan lama inkubasi 1 jam dengan konsentrasi enzim biduri dan papain $0 \%$ (tanpa enzim) menghasilkan derajat hidrolisis terendah yaitu $60,886 \%$, sedangkan pada perlakuan lama inkubasi 2 jam dengan konsentrasi enzim biduri dan papain 3\% menghasilkan derajat hidrolisis tertinggi yaitu $96,81 \%$. Pada penelitian Witono et al. (2014) diperoleh nilai derajat hidrolisis dari hidrolisat protein ikan bibisan sebesar 11,98\% dari perlakuan terbaik kombinasi enzim biduri dan papain 30:70\% dengan lama hidrolisis 1,5 jam sedangkan pada penelitian Baehaki et al. (2015) diperoleh nilai derajat hidrolisis sebesar $71,98 \%$ dari perlakuan penambahan enzim papain konsentrasi $6 \%$. Nilai derajat hidrolisis dari hidrolisat biji bunga matahari+kupang putih pada perlakuan lama fermentasi 2 jam dengan konsentrasi enzim biduri dan papain 3\% pada penelitian ini lebih tinggi dbandingkan dengan hasil penelitian Witono et al. (2014) dan Baehaki et al. (2015).
Derajat hidrolisis adalah parameter untuk mengetahui sejauh mana reaksi hidrolisis protein terjadi. Diketahui bahwa lama fermentasi dan konsentrasi enzim berpengaruh nyata terhadap derajat hidrolisis dari hidrolisat biji bunga matahari+kupang putih. Perlakuan lama inkubasi 2 jam menghasilkan nilai derajat hidrolisis yang lebih tinggi dibandingkan dengan lama fermentasi 3 jam. Hal ini disebabkan karena inkubasi yang semakin lama menyebabkan proses hidrolisis lebih lanjut oleh kapang sehingga meningkatkan molekul peptida rantai pendek sehingga berakibat pada derajat hidrolisis yang makin tinggi. Hal ini sesuai dengan Rahayu et al. (2019) bahwa derajat hidrolisis tempe koro benguk mengalami kenaikan tajam pada 24 jam pertama, inkubasi yang lebih lama sedikit menaikkan DH tetapi tidak setajam di awal fermentasi, kemudian setelah 48 jam fermentasi, prosentase protein terhidrolisis relative stabil (sekitar 45\%).

Konsentrasi enzim biduri dan papain 3\% menghasilkan derajat hidrolisis yang tinggi kemudian menurun. Hal tersebut disebabkan karena dalam mempercepat pemutusan ikatan peptida untuk menghasilkan derajat hidrolisis yang lebih tinggi pada waktu yang sama dibutuhkan konsentrasi enzim biduri dan papain yang tepat.

Kombinasi dari endo-peptidase dan eksopeptidase yang dilaporkan Rawlings et al. (2007) dalam menghidrolisis protein diawali dengan menggunakan endo-peptidase untuk memecah protein menjadi peptida dan dilanjutkan dengan ekso-peptidase untuk memecah peptida menjadi asam amino atau peptida berantai pendek. Semakin rendah jumlah unit enzim papain yang ditambahkan mengakibatkan derajat hidrolisis yang menurun, hal

Tabel 2. Karakteristik penyedap alami dari biji bunga matahari dan kupang putih perlakuan lama inkubasi dan konsentrasi campuran enzim protease

\begin{tabular}{|c|c|c|c|c|c|c|}
\hline \multicolumn{2}{|c|}{ Perlakuan } & \multirow[b]{2}{*}{$\begin{array}{c}\text { Derajat } \\
\text { Hidrolisis (\%) }\end{array}$} & \multirow[b]{2}{*}{$\begin{array}{c}\text { Protein Terlarut } \\
(\%)\end{array}$} & \multirow[b]{2}{*}{$\begin{array}{l}\text { Produk Maillard } \\
\text { (UA) }\end{array}$} & \multirow[b]{2}{*}{$\begin{array}{l}\text { Indeks Kelarutan } \\
\text { Air }(\mathrm{g} / \mathrm{mL})\end{array}$} & \multirow{2}{*}{$\begin{array}{c}\text { Daya Serap } \\
\text { Minyak } \\
(\mathrm{mL} / \mathrm{g})\end{array}$} \\
\hline $\begin{array}{l}\text { Lama inkubasi } \\
\text { (Jam) }\end{array}$ & $\begin{array}{c}\text { Kons. Enzim } \\
(\%)\end{array}$ & & & & & \\
\hline 1 & \multirow{3}{*}{. } & $60,89 \pm 0,21^{\mathrm{h}}$ & $11,31 \pm 0,11^{\mathrm{f}}$ & $0,051 \pm 0,003^{\mathrm{g}}$ & $0,012 \pm 002^{\mathrm{h}}$ & $3,97 \pm 019^{\mathrm{a}}$ \\
\hline 2 & & $63,95 \pm 0,14 \mathrm{f}^{\mathrm{g}}$ & $13,46 \pm 0,08^{\mathrm{ef}}$ & $0,076 \pm 0,002^{\mathrm{fg}}$ & $0,017 \pm 001^{\mathrm{fg}}$ & $2,31 \pm 022^{c}$ \\
\hline 3 & & $74,42 \pm 0,22^{\mathrm{e}}$ & $16,61 \pm 0,23^{\mathrm{e}}$ & $0,086 \pm 0,001^{\mathrm{ef}}$ & $0,024 \pm 003^{\mathrm{e}}$ & $2,21 \pm 023^{\mathrm{cd}}$ \\
\hline 1 & \multirow{3}{*}{1,5} & $87,41 \pm 0,18^{c}$ & $35,91 \pm 0,24^{\mathrm{c}}$ & $0,136 \pm 0,001^{\mathrm{bcd}}$ & $0,031 \pm 003^{\text {cd }}$ & $2,02 \pm 017^{\mathrm{e}}$ \\
\hline 2 & & $88,08 \pm 0,14^{\mathrm{c}}$ & $36,56 \pm 0,17^{\mathrm{c}}$ & $0,141 \pm 0,003^{\text {bc }}$ & $0,033 \pm 002^{\mathrm{bc}}$ & $2,01 \pm 011^{\mathrm{e}}$ \\
\hline 3 & & $91,24 \pm 0,11^{\mathrm{b}}$ & $43,96 \pm 0,41^{\mathrm{b}}$ & $0,159 \pm 0,002^{\mathrm{b}}$ & $0,034 \pm 004^{\mathrm{ab}}$ & $2,01 \pm 029^{\mathrm{e}}$ \\
\hline 1 & \multirow{3}{*}{3,0} & $96,09 \pm 0,12^{\mathrm{a}}$ & $47,26 \pm 0,22^{\mathrm{a}}$ & $0,189 \pm 0,002^{\mathrm{a}}$ & $0,037 \pm 001^{\mathrm{a}}$ & $1,82 \pm 036^{\mathrm{f}}$ \\
\hline 2 & & $96,81 \pm 0,24^{\mathrm{a}}$ & $52,86 \pm 0,09^{\mathrm{b}}$ & $0,162 \pm 0,002^{\mathrm{ab}}$ & $0,036 \pm 001^{\mathrm{ab}}$ & $1,88 \pm 016^{\mathrm{f}}$ \\
\hline 3 & & $81,45 \pm 0,09^{d}$ & $30,06 \pm 0,07^{\mathrm{d}}$ & $0,111 \pm 0,004^{\mathrm{de}}$ & $0,028 \pm 002^{\mathrm{de}}$ & $2,19 \pm 023^{\mathrm{d}}$ \\
\hline 1 & \multirow{3}{*}{4,5} & $84,23 \pm 0,09^{d}$ & $31,51 \pm 0,19^{d}$ & $0,121 \pm 0,001^{\text {cd }}$ & $0,028 \pm 001^{\mathrm{de}}$ & $2,13 \pm 022^{\mathrm{d}}$ \\
\hline 2 & & $65,04 \pm 0,12^{\mathrm{f}}$ & $14,31 \pm 0,21^{\mathrm{ef}}$ & $0,077 \pm 0,001^{\mathrm{fg}}$ & $0,018 \pm 002^{\mathrm{f}}$ & $2,22 \pm 012^{\mathrm{cd}}$ \\
\hline 3 & & $61,69 \pm 0,05^{\mathrm{gh}}$ & $11,36 \pm 0,12^{\mathrm{f}}$ & $0,066 \pm 0,003^{\mathrm{fg}}$ & $0,013 \pm 001^{\mathrm{gh}}$ & $3,99 \pm 033^{b}$ \\
\hline
\end{tabular}

Keterangan: Angka yang diikuti huruf yang sama menyatakan tidak berbeda nyata pada uji DMRT $(a=0,05)$. 
ini diduga karena efek hidrolitik dari endopeptidase menurun sehingga ketersediaan peptida yang lebih kecil yang berfungsi sebagai hidrolisis lebih lanjut oleh ekso-peptidase berkurang. Storer dan Menard (2013) mengemukakan bahwa papain mengandung empat enzim sistein endo-peptidase yang berbeda yang menunjukkan spesifisitas lebih luas, sehingga efek hidrolitiknya tinggi.

\section{Kadar Protein Terlarut}

Rata-rata kadar protein terlarut penyedap rasa dari hidrolisat biji bunga matahari+kupang putih pada Tabel 2, berkisar antara 11,31-52,86\%. Perlakuan lama fermentasi 1 jam dengan konsentrasi enzim biduri dan papain $0 \%$ menghasilkan kadar protein terlarut terendah yaitu $11,31 \%$ sedangkan perlakuan lama inkubasi 2 jam dengan konsentrasi enzim biduri dan papain 3\% menghasilkan kadar protein terlarut tertinggi yaitu $52,86 \%$. Nilai protein terlarut dari penyedap rasa hidrolisat biji bunga matahari+kupang putih perlakuan lama fermentasi 2 jam dengan konsentrasi enzim biduri dan papain $3 \%$ pada penelitian ini lebih tinggi dibandingkan dengan hasil penelitian Witono et al. (2014) dengan nilai kadar protein terlarut sebesar $41,91 \%$ dari hidrolisat protein ikan bibisan perlakuan kombinasi enzim biduri dan papain rasio 70\%:30\% dengan waktu hidrolisis 1,5 jam. Perlakuan lama inkubasi 2 jam menghasilkan penyedap rasa dengan kadar protein terlarut yang lebih tinggi dibandingkan dengan inkubasi 3 jam. Hal ini disebabkan selama inkubasi terjadi degradasi makronutrien menjadi komponen peptida, semakin lama waktu inkubasi, menurut Utami (2014) maka komponen peptida terpecah lebih lanjut menjadi komponen yang memiliki berat molekul lebih kecil dengan kelarutan air yang lebih tinggi (Nount dan Kiers, 2005). Konsentrasi enzim $3 \%$ menghasilkan kadar protein terlarut tertinggi kemudian menurun seiring dengan meningkatnya konsentrasi enzim biduri dan enzim papain. Hal ini disebabkan karena papain sebagai endo-peptidase bertugas menyediakan peptida rantai pendek dengan memotong ikatan peptida pada bagian tengah untuk kemudian dihidrolisis lebih lanjut oleh enzim biduri sebagai ekso-peptidase dengan memutus ikatan peptida pada bagian luar, dengan menurunnya konsentrasi enzim papain yang ditambahkan maka semakin sedikit peptida-peptida sederhana yang dihasilkan. Hal ini sesuai dengan Witono, et al. (2014) bahwa ketersediaan protein rantai pendek menurun dengan semakin berkurangnya proporsi enzim papain.

\section{Produk Maillard}

Salah satu produk Maillard adalah senyawa melanoidin yaitu pigmen berwarna coklat hasil interaksi dari produk hidrolisis (amina primer) dengan gula reduksi (Kusnandar, 2010) yang dapat dianalisa dengan cara absorbansi. Rata-rata produk Maillard penyedap rasa dari hidrolisat biji bunga matahari+kupang putih berkisar antara 0,051-0,189 AU. Perlakuan lama inkubasi 1 jam dengan konsentrasi enzim $0 \%$ menghasilkan produk Maillard terendah yaitu 0,051 AU sedangkan perlakuan lama inkubasi 1 jam dengan konsentrasi enzim 3\% menghasilkan produk Maillard tertinggi yaitu 0,189 AU. Menurut Witono et al. (2014) dengan nilai Maillard sebesar 0,74 dari hidrolisat protein ikan bibisan perlakuan kombinasi enzim biduri dan papain rasio 30\%:70\% dengan waktu hidrolisis 1,5 jam.

Produk Maillard dinyatakan dalam absorbansi unit, semakin tinggi absorbansi maka produk Maillard semakin tinggi. Dapat diketahui bahwa lama inkubasi dan konsentrasi enzim berpengaruh nyata terhadap produk Maillard penyedap rasa dari hidrolisat biji bunga matahari+kupang putih. Perlakuan lama inkubasi 1 jam menghasilkan penyedap rasa dengan produk Maillard yang lebih tinggi dibandingkan dengan inkubasi 3 jam. Hal ini disebabkan karena semakin lama fermentasi maka degradasi makronutrien menjadi komponen peptida dan asam amino semakin tinggi, sehingga ketersediaan asam amino untuk bereaksi dengan gula reduksi semakin banyak. Hal ini sesuai dengan penelitian Witono (2007) bahwa semakin lama hidrolisis, maka hidrolisat protein kedelai yang dihasilkan semakin gelap (kecoklatan). Hal ini karena semakin lama hidrolisis nilai produk Maillard yang dihasilkan semakin banyak sehingga warna hidrolisat semakin gelap. Melalui hidrolisis enzimatis suatu bahan pangan berprotein, maka akan dihasilkan asam-asam amino dan peptidapeptida pendek yang berperan sebagai prekursor terjadinya reaksi Maillard (Witono, 2011). Produk Maillard merupakan hasil interaksi dari produk hidrolisis (amina primer) dengan gula reduksi sehingga berhubungan dengan kadar protein terlarut, semakin tinggi kadar protein terlarut maka semakin tinggi produk maillardnya. Hal ini disebabkan karena papain sebagai endo-peptidase bertugas menyediakan peptida rantai pendek, semakin banyak enzim papain yang ditambahkan maka semakin banyak peptida-peptida sederhana yang dihasilkan. Menurut Witono et al. (2014) Hal ini terjadi karena aktivitas enzim papain semakin tinggi 
sehingga memperbanyak protein rantai pendek dan meningkatkan gugus amina primer. Semakin banyak ikatan peptida yang dihidrolisis dengan demikian gugus amina primer yang dihasilkan semakin banyak. Reaksi maillard merupakan reaksi antara gugus karbonil dan gugus amina primer (Witono, 2014).

\section{Indeks Kelarutan Air}

Indeks kelarutan air adalah kemampuan flavor enhancer untuk larut dalam air yang dikaitkan dengan sifat fungsional protein (Estiasih dan Ahmadi, 2009). Rata-rata indeks kelarutan air penyedap rasa dari biji bunga matahari dan kupang putih berkisar antara 0,012-0,037 g/mL. Perlakuan lama inkubasi 1 jam dengan konsentrasi enzim $0 \%$ (kontrol) menghasilkan indeks kelarutan air terendah yaitu $0,012 \mathrm{~g} / \mathrm{mL}$ sedangkan perlakuan lama fermentasi 1 jam dengan konsentrasi enzim biduri dan papain 3\% menghasilkan indeks kelarutan air tertinggi yaitu $0,037 \mathrm{~g} / \mathrm{mL}$.

Lama inkubasi dan konsentrasi enzim berpengaruh nyata terhadap indeks kelarutan air. Perlakuan lama inkubasi menghasilkan penyedap rasa dengan indeks kelarutan air yang semakin tinggi, namun jika waktu diperpanjang maka indeks kelarutan akan turun. Hal ini disebabkan selama inkubasi terjadi degradasi makronutrien menjadi komponen peptida, semakin lama waktu inkubasi menurut Utami (2014) maka komponen peptida terpecah lebih lanjut menjadi komponen yang memiliki berat molekul lebih kecil dengan kelarutan air yang lebih tinggi (Nount dan Kiers, 2005)

Kombinasi dua enzim dengan konsentrasi 3\% menghasilkan penyedap alami dengan indeks kelarutan air tertinggi kemudian menurun seiring dengan seiring meningkatnya konsentrasi enzim. Kelarutan air produk hidrolisat berhubungan dengan kadar protein terlarutnya, peptida rantai pendek hasil hidrolisis memiliki berat molekul yang rendah sehingga meningkatkan kelarutannya. Hal ini sesuai dengan Nurhayati et al. (2013) bahwa kelarutan yang tinggi pada hidrolisat protein disebabkan oleh pemecahan protein menjadi peptida yang lebih sederhana. Hidrolisis ikatan peptida akan menyebabkan beberapa perubahan pada protein, yaitu meningkatkan kelarutan karena bertambahnya kandungan $\mathrm{NH}^{3+}$ dan $\mathrm{COO}^{-}$serta berkurangnya berat molekul protein atau polipeptida (Wilson dan Walker, 2000).

\section{Daya Serap Minyak}

Sifat fungsional serbuk biasanya terkait dengan interaksi antara air dan minyak. Pengukuran daya serap minyak didefinisikan sebagai sifat pengikatan lemak/minyak secara fisika oleh protein yaitu protein menyerap, menahan, dan bereaksi dengan minyak dalam sistem emulsi. Kapasitas penyerapan minyak yang besar dapat meningkatkan flavor dan mouth feel pada makanan.

Perlakuan lama 1 jam dengan konsentrasi enzim 3\% menghasilkan daya serap lemak terendah yaitu $1,82 \mathrm{~mL} / \mathrm{g}$, sedangkan lama inkubasi 1 jam konsentrasi enzim 4,5\% menghasilkan nilai daya serap minyak $3,99 \mathrm{~mL} / \mathrm{g}$. Nilai daya serap minyak pada perlakuan lama inkubasi dan konsentrasi campuran enzim berbeda nyata karena kapasitas pengikatan minyak dipengaruhi oleh kadar protein terlarutnya. Semakin lama waktu inkubasi maka kadar protein terlarutnya semakin tinggi, dan semakin tinggi konsentrasi enzim, kadar protein terlarutnya semakin tinggi pula. Hal ini sesuai dengan Koesoemawardani dan Hadiwiyoto (2001) kapasitas pengikatan minyak dipengaruhi oleh derajat hidrolisis, dalam hal ini derajat hidrolisis sejalan dengan protein terlarut.

Hasil daya serap minyak berbanding terbalik dengan protein terlarut, semakin tinggi protein terlarut maka semakin rendah kapasitas penyerapan minyaknya. Hal ini dikarenakan selama hidrolisis terjadi pemotongan molekul protein menjadi peptida pendek atau asam amino yang memiliki gugus berbeda satu sama lain yaitu hidrofobik dan hidrofilik, gugus hidrofobik berhubungan dengan kapasitas penyerapan minyak sedangkan gugus hidrofilik berhubungan dengan kapasitas penyerapan air sehingga apabila kadar protein terlarutnya tinggi maka jumlah gugus hidrofobiknya sedikit. Hal ini sesuai dengan Koesoemawardani et al. (2012), hasil penelitian menunjukkan bahwa dengan meningkatnya protein terlarut maka kapasitas pengikatan minyak menurun.

\section{Analisis Profil Asam Amino}

Profil asam amino dianalisis untuk menunjukkan bahwa terdapat asam glutamat yang cukup tinggi pada produk setelah hidrolisis enzimatis menggunakan campuran endo- dan ekso-peptidase. Tingginya kadar asam amino glutamat pada hidrolisat biji bunga matahari dan kupang putih tersebut, menyebabkan produk yang dihasilkan layak digunakan sebagai penyedap rasa. Berdasarkan hasil analisis terhadap parameter-parameter yang diuji, maka perlakuan terbaik adalah konsentrasi enzim biduri:papain 3\% dan lama inkubasi 2 jam, berdasarkan parameter utama yaitu derajad hidrolisis. 
Derajad hidrolisis pada perlakuan tersebut adalah yang tertinggi yaitu 52,86\%, selanjutnya hidrolisat pada perlakuan tersebut diuji kadar asam glutamatnya menggunakan UPLC. Analisis asam glutamat juga dilakukan terhadap biji bunga matahari dan kupang putih. Hasil analisis analisis asam glutamat dapat dilihat pada Tabel 3.

Tabel 3. Kadar asam glutamate pada biji bunga matahari, kupang putih dan hidrolisat biji bunga matahari dan kupang putih

\begin{tabular}{lc}
\hline \multicolumn{1}{c}{ Sampel } & $\begin{array}{c}\text { Asam Glutamat } \\
(\mathrm{mg} / \mathrm{g})\end{array}$ \\
\hline Biji bunga matahari & $44,445 \pm 0,27$ \\
Kupang putih & $55,427 \pm 0,92$ \\
Penyedap rasa (hidrolisat) & $78,678 \pm 0,56$ \\
\hline
\end{tabular}

Pada Tabel 3, dapat dilihat bahwa penyedap rasa dari hidrolisat biji bunga matahari dan kupang putih yang diperoleh dari hidrolisis menggunakan campuran endo- dan ekso-enzim protease konsentrasi $3 \%$, lama inkubasi 2 jam adalah

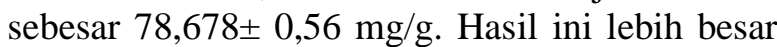
dibandingkan dengan hasil penelitian Witono et al. (2015), yang menghasilkan 55,84 mg/g. Perbedaan ini disebabkan karena pada penelitian Witono et al. (2015) perlakuan hidrolisis hanya menggunakan enzim calotropin dari getah biduri, bahan baku yang digunakan adalah tempe over fermentasi. Menurut Vogel dan May (2019) untuk meningkat hasil hidrolisis diperlukan sinergisme melalui penggunaan kombinasi protease dari berbagai sumber biologis yang digunakan secara berurutan atau paralel. Enzim calotropin sebagai eksopeptidase dalam memutus ikatan peptida terminal dari protein globular yang utuh membutuhkan perla-kuan pendahuluan atau gabungan dengan endo-peptidase yaitu papain untuk memutus ikatan peptida dari tengah rantai.

\section{KESIMPULAN}

Kombinasi enzi endo- dan ekso-protease lama inkubasi dapat meningkatkan derajad hidrolisis kadar protein terlarut, indeks kelarutan air dan daya serap minyak penyedap rasa dari hidrolisat biji bunga matahari dan kupang puti. Perlakuan terbaik pada penelitian ini konsentrasi enzim calotropin: papain 3\% dan lama inkubasi 2 jam, menghasilkan penyedap rasa dengan karakteristik: derajat hidrolisis 96,81\%; kadar protein terlarut $52,86 \%$; produk maillard $0,162 \%$; indeks kelarutan air 0,036; daya serap minyak $1,88 \%$ dan kadar asam glutamat mencapai $78,678 \mathrm{mg} / \mathrm{g}$.

Biji bunga matahari yang dikombinasi dengan kupang putih sangat potensial untuk dikembangkan sebagai penyedap rasa alami untuk menggatikan MSG. Penggunaan kombinasi endodan ekso-protease lebih efektif dibandingkan penggunaan enzim tunggal.

\section{UCAPAN TERIMA KASIH}

Ucapan terima kasih disampaikan kepada UPN "Veteran" Jawa Timur yang telah memberikan dana penelitian melaluai RISET DASAR LANJUTAN TA 2019-2020. Ucapan terima kasih juga disampaikan kepada Kalisa Mawarni Putri alumni Program Studi Teknologi Pangan, yang telah membantu dalam pelaksanaan penelitian ini.

\section{DAFTAR PUSTAKA}

Adler-Nissen, J. 1986. Enzymatic Hidrolysis of Food Proteins. London: Elsevier Applied Science Publishers Ltd. pp: 57-109.

BPOM. 2006. Pemanfaatan Zat Aditif Secara Tepat. Direktorat Surveilan dan Penyuluhan Keamanan Pangan. Lampung.

Badan Standarisasi Nasional. 2000. No. 01-42731996. Tentang Bumbu Penyedap Rasa. Badan Standarisasi Nasional. Jakarta.

Clemente, A. 2000. Enzymatic protein hydrolisates in human nutrition. Journal of Food Science and Technology 11: 254-262. DOI: 10.1016/S0924-2244(01)00007-3

Dongoran, D.S. 2004. Pengaruh aktivator sistein dan natrium klorida terhadap aktivitas papain. Jurnal Sains Kimia 8: 26-28.

Dwivedi, A., G.N, and Sharma. 2014. A review on heliotropim plant: Helianthus annuus L. Journal of Phytopharmacology 3: 149-155.

Fakhrudin, A. 2009. Pemanfaatan Air Rebusan Kupang Putih (Corbula faba Hind) untuk Pengolahan Petis dengan Penambahan Berbagai Pati-patian. Skripsi. Institut Pertanian Bogor. Bogor.

Koesoemawardani, D. dan S. Hadiwiyoto. 2001. Produksi Hidrolisat Protein Ikan Kembung. Thesis, Universitas Gadjah Mada. Yogyakarta.

Koesoemawardani, D., F. Nurainy, dan S. Hidayati. 2011. Proses pembuatan hidrolisat protein ikan rucah. Jurnal Natur Indonesia 13: 256-261. 
Ksumastyaningrum, D. 2002. Pengaruh Antioksidan dan Aktivator untuk Mempertahankan Aktivitas Proteolitik Getah Pepaya Selama Penyimpanan. Skripsi: Institut Pertanian Bogor. Bogor.

Kumara, B. 2006. Meat flavor imitation berbasis reaksi maillard. Food Review 1: 42-49.

Maga, J.A. 1998. Umami Flavor of Meat. In: Shahidi, F. (Ed.). Flavor of Meat, Meat Products and Seafoods. Blackie Academic \& Professional. London. pp: 197-215.

Mujianto, Y. Witono, Wignyanto, S. Kumalaningsih, and Auliani'am. 2018. Hydrolysis characteristics of over fermented tempe (Fermented Soybean Cake) Product hydrolyzed by enzymatic hydrolyzed as natural flavor source (flavor enhancer). Indian Journal of Nutrition and Dietetics 55: 29-43.

Purwandani, L.A. 2015. Penambahan Bahan Pengisi dan Variasi Teknik Pengeringan pada Pembuatan Hidrolisat Ikan Inferior Hasil Hidrolisis Enzimatis. Skripsi. Universitas Jember. Jember.

Purwanto, dan A. Sardjimah. 2000. Kupang sebagai Alternatif Sumber Protein. Prosiding Seminar Nasional Makanan Tradisional PKMT. Universitas Brawijaya. Malang.

Silva, G.M.S.W. and M.A.J. Wansapala. 2016. Formulation of flavor enhancer using locally available natural raw materials. International Journal of Innovative Research in Technology 2: 77-86.

Subani, W. Suwiryo, dan Suminarti. 1983. Laporan Penelitian Perikanan Laut Nomor 23 BPPL: Penelitian Lingkungan Hidup Perairan Kupang, Pemanfaatan Hasil dan Pelestarian Sumbernya. Departemen Pertanian. Jakarta.

Susanti, R. 2017. Teknologi Enzim. Edisi I. Penerbit Andi. Yogyakarta. Hal. 114-115.

Suyanti, Setyadjit, dan A.B. Arif. 2012. Produk diversifikasi olahan untuk meningkatkan nilai tambah dan mendukung pengembangan buah pepaya (Carica papaya
L) di Indonesia. Buletin Teknologi Pascapanen Pertanian 8: 63-69.

Temussi, P.A. 2011. The good taste of peptides. Journal of Peptide Science 18: 73-82.

Tseng, Y.H., Y.L. Lee, R.C. Li, J.L. Mau. 2005. Non-Volatile flavor components of Ganoderma tsugae. Food Chemistry 90: 409415.

Walker, J.M. 1994. The Protein Protocols Handbook. Totowa: Humana Press Inc. pp. 726.

Wijayanti, R.P. 2016. Formulasi Flavor Enhancer dari Hidrolisat Protein Ikan Wader. Skripsi. Universitas Jember. Jember.

Winarti, S. Jariyah, dan Y. Purnomo. 2007. Proses pembuatan VCO (Virgine Coconut Oil) secara enzimatis menggunakan papain kasar. Jurnal Teknologi Pangan 8: 136-141.

Witono, Y., Aulanni'am, A. Subagio, dan S.B. Widjanarko. 2007. Karakteristik hidrolisat protein kedelai dari proses hidrolisis secara enzimatis menggunakan protease dari tanaman biduri. Berkala Penelitian Hayati 3: 7-13.

Witono, Y., W.S. Windrati, dan H. Puspitasari. 2011. Uji Hidrolisis dan Modifikasi Proses Hidrolisis Protease Biduri pada Subrat Koro Kratok. Prosiding Seminar NasionalPerhimpunan Teknik Pertanian. Jember.

Witono, Y. 2013. Enzim Biduri: Agen Aktif Potensial untuk Proses Pangan. Surabaya: Pustaka Radja. Hal: 1-91.

Witono, Y. 2014. Teknologi Flavor Alami Berbasis Proses Hidrolisis Enzimatis. Surabaya: Pustaka Radja. Hal: 5-76.

Witono, Y., S.B. Widjanarko, Mujianto, and D.T. Rachmawati. 2015. Amino acid identification of over fermented tempeh, the hydrolysate and the seasoning product hydrolysed by calotropin from crown flower (Calotropis gigantea). International Journal of Advanced Science Enginering Information Technology 5: 103-106.

Witono, Y. 2017. Teknologi Flavor Ikan 1. Surabaya: Pustaka Radja. Hal 27. 